\title{
Effects of Light and Temperature on Seed Germination in Cecropia hololeuca Miq. (Cecropiaceae)
}

\author{
Simone Godoi ${ }^{1}$ and Massanori Takaki ${ }^{2 *}$ \\ ${ }^{l}$ Faculdade de Ciências; Matemáticas e da Natureza; UNIMEP; Piracicaba - SP - Brazil. ${ }^{2}$ Departmento de \\ Botânica; UNESP; C. P. 199; 13506-900; Rio Claro - SP - Brazil
}

\begin{abstract}
Seeds of Cecropia hololeuca were submitted to regimes of constant and alternating temperatures, associated with photoperiods of white light, "shade light" and continuous darkness under controlled conditions in laboratory. Seeds did not germinate at constant temperatures of $10^{\circ} \mathrm{C}$ to $20^{\circ} \mathrm{C}$ and above $35^{\circ} \mathrm{C}$. Seeds only germinated in the darkness when the temperature was alternated. "Shade light" inhibited germination. We concluded that the regime of alternating temperatures suppressed the light effects on seed germination of this species.
\end{abstract}

Key words: Cecropia hololeuca, germination, alternating temperature, phytochrome, light

\section{INTRODUCTION}

The knowledge of seed biology is essential for understanding the process and patterns within a given plant community, such as the establishment of plants, succession and natural regeneration (Vázquez Yanes and Orozco-Segovia, 1993). Whitmore (1989) designated the forest as being a spatial mosaic of structural phases with a dynamic process of continuous changes. In such habitat, an initial disturbance-induced cycle allows us to recognize the three most important phases of a forest: gap, regeneration and mature phase. Gaps formed by fallen trees or branches generally are considered as important factors in the maintenance of the high species diversity in the tropical forest (Hartshorn, 1989).

The light radiation within a gap habitat is typically characterized by a period of direct solar radiation interspaced by periods of diffuse radiation and by occasional sunflecks (Smith et al., 1989; Wayne and Bazzaz, 1993). Light-controlled germination has been associated with phytochrome since the pioneer work of Borthwick et al. (1952). The sensitivity of seeds to the spectral quality of the light mediated by phytochrome is a frequent natural process within species that colonize open areas (Ballaré, 1994). In gaps, the temperatures of the soil are significantly higher, with the maximum variation occurring at the soil surface. This pattern leads to a daily fluctuation that can accelerate the germination and/or modify the response of light sensitive species (Malavasi, 1989; Orozco-Segovia and Vázquez Yanes, 1992). According to Labouriau and Pacheco (1978), the effects of the temperature can be evaluated from changes in the percentage, velocity and relative frequency of germination during the incubation time.

Seeds from different species require alternating of temperatures to optimize germination. This necessity most probably reflects an adaptation to natural fluctuation of the habitat or may be associated with dormancy process. Whatever the

\footnotetext{
*Author for correspondence
} 
cause, this requirement can confer, in most cases, an adaptive advantage for the species. (Borges and Reindeer, 1993; Copeland and McDonald, 1995). In the present work we investigated the effects of light and temperature (constant and alternating) on the seed germination of Cecropia hololeuca (Cecropiaceae). This species, commonly named as silver-embaúva, black-embaúva or whiteembaúba, can reach from of 6 to 12 meters of height, with a distribution from south of Bahia, Espírito Santo, Rio de Janeiro, Minas Gerais and São Paulo Sates, mainly in the pluvial forest (Lorenzi 1992).

The genus Cecropia is represented, from the central to the south part of Brazil, by three species: C. hololeuca, C. glasioui and C. pachystachya. C. hololeuca and $C$. glasioui are usually found in small gaps, while $C$. pachystachya is found in open areas and larger gaps. The seeds are small and numerous and the fruits are dispersed by birds and bats (Gandolfi 2000).

\section{MATERIAL AND METHODS}

Seeds of Cecropia hololeuca were obtained from the Paraibúna Station of the Companhia Energética de São Paulo (CESP). Germination tests were carried out in 4 Petri-dishes, containing 50 seeds each, on two layers of water moistened filter paper. During the experiments, these Petridishes were maintained in germination incubators (FANEM). The effect of the temperature on seed germination was investigated by exposing the seeds to constant temperatures of 10, 15, 20, 25, $30, \quad 35$ and $40^{\circ} \mathrm{C}$ and under alternating temperatures of $20-25,20-30$ and $20-35^{\circ} \mathrm{C}$, under photoperiod of 12 hours and continuous darkness. In experiments with continuous darkness, the Petri-dishes were placed inside "gerbox" (black) boxes. In experiments with alternating temperature, the light period was always associated with the highest temperature. In order to mimic the light conditions faced by seeds of $C$. hololeuca in their natural habitats, we exposed the seeds to a "shade light", which correspond to the light filtered by the canopy in relation to the ratio Red:Far Red light (R:FR). This light was obtained by using 4 incandescent bulb lamps (white light) of $25 \mathrm{~W}$ each filtered by a red and a blue layer of plexiglass, and one uncovered day-light fluorescent lamp (15W). In our experimental conditions, the R:FR ratio was 0.077 and, accordingly to Mancinelli (1994), the calculated photoequlibrium of phytochrome was 0.18 . Under the "shade light" conditions, seeds were exposed to the following photoperiods: 1) 8 hours of white light with 2 hours before and after of "shade light"; 2) 10 hours of white light with 1 hour before and after of "shade light"; 3) 12 hours of white light with $30 \mathrm{~min}$ before and after of "shade light"; 4) 13 hours of white light with $15 \mathrm{~min}$ before and after of "shade light"; and 5) continuous "shade light". In these experiments, we used the regime of alternating temperatures as previously described. In order to prevent a "flash" of white light at the end of the illumination period, which could reverse the effect of "shade light", the F:FR light was turned off 15 min after white light was turned off. Daily counts of the germinated seeds allowed us to verify the dynamics of germination. We considered a seed to be germinated when the root had at least $1 \mathrm{~mm}$ of length and/or showed signals of geotropic movements. In the experiments carried out under continuous darkness, the seeds were counted and observed under a dim green safe light (Baroli and Takaki, 2001).

The values of relative frequency and mean velocity of germination were calculated according to Labouriau and Sharp (1987). The synchronization index was calculated following Labouriau (1983). We used a Two-Way Analysis of Variance to test for the combined (interaction) and isolated effects of the temperature and photoperiod on the percentage and mean velocity of germination. Whenever this result was significant, a Student-Newman Keuls's test (SNK) was used a posteriori. Before applying the test, we performed an arcsine transformation to the percentage data, and test to the assumptions of normality and homogeneity of variances. All tests followed Sokal and Rohlf (1983), and an alpha level of 0.05 was adopted as significant in all circumstances. 

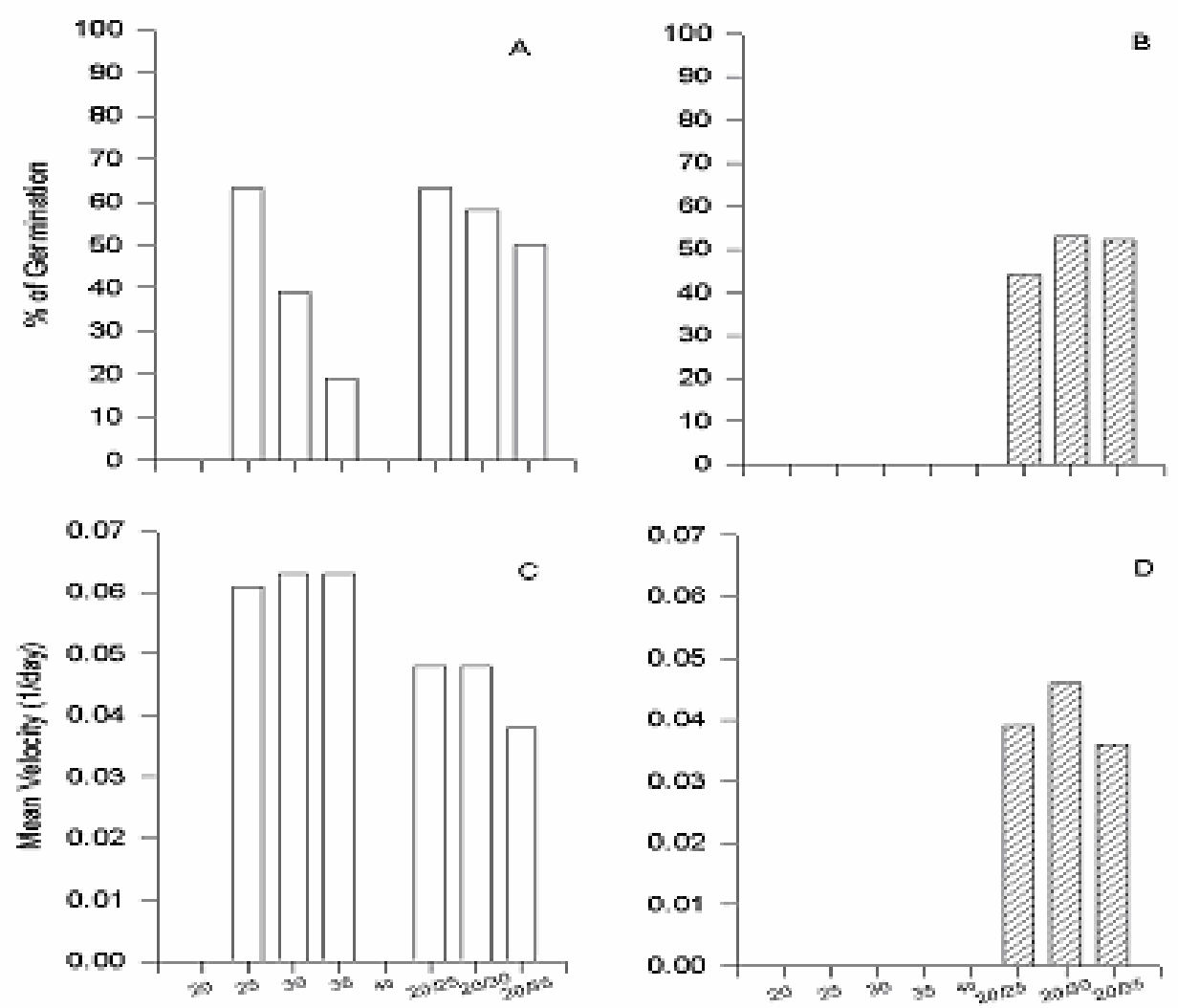

Temperature $\left({ }^{\circ} \mathrm{C}\right)$

Figure 1 - Variation in the percentage (A and B) and mean velocity (C and D) of germination of Cecropia hololeuca as a function of the thermal regime and photoperiod. Photoperiods encompass regimes of 12 hours light and 12 hours darkness (A and C) and continuous darkness (B and D). See text for further details.

Table 1 - Summary of the results from the Two-Way Analysis of Variance on the effects of photoperiod, temperature and interaction of both factors on the percentage of germination (upper values) and mean velocity of germination (bottom values) of seeds of Cecrophia hololeuca. See text for further details.

\begin{tabular}{l|c|c|c}
\hline Source of Variation & DF & F test & Probability \\
\hline Temperature & 1 & 151.3 & $<0.0001$ \\
& & 38.3 & $<0.0001$ \\
Photoperiod & 1 & 234.6 & $<0.0001$ \\
& & 276.6 & $<0.0001$ \\
Interaction & 1 & 205.1 & $<0.0001$ \\
Residual & 28 & 212.5 & \\
\hline Total & 31 & & \\
\hline
\end{tabular}




\section{RESULTS AND DISCUSSION}

Temperature and photoperiod affected the percentage and mean velocity of germination of seeds of $C$. hololeuca. This influence was significant both when the variables were analyzed in isolation or when the interaction between them was taken into account (Fig. 1 and Table 1). The interaction was more evident when the seeds were maintained in constant temperatures (from 10 to $40^{\circ} \mathrm{C}$ ) and in continuous darkness. Under continuous darkness, no germination occurred, a result that greatly differed form the one obtained when the seeds were also maintained in this light regime, but under a regime of alternating temperatures. (Fig. 1B and 1D). In seeds exposed to regimes of alternating temperatures, the effect of photoperiod on the percentage and mean velocity of germination was modified; however, the magnitude and the pattern of this modification greatly differed within and among the analyzed parameters (Fig. 1).

Exposing the seeds to a regime of alternating temperatures totally suppressed the effects of the photoperiod on the percentage of germination. When seeds were maintained in continuous darkness, in alternating temperatures, the percentage germination at $20-25^{\circ} \mathrm{C}(44 \%), 20$ $30^{\circ} \mathrm{C}(53 \%)$ and $20-35^{\circ} \mathrm{C}(52 \%)$ did not differ from the values observed for seeds exposed to the same range of temperatures in a photoperiod of 12 hours (SNK - P > 0,05 for all the comparisons). Válio and Scarpa (2001) showed that $91 \%$ of seeds of C. hololeuca germinated at a constant temperature of $25^{\circ} \mathrm{C}$ at photoperiod of 12 hours. On the other hand, seeds maintained under the same temperature regime, but in constant darkness, failed to germinate. These authors also reported that alternating temperatures between $35-10^{\circ} \mathrm{C}$, under a photoperiod of 12 hours, resulted in a percentage of germination of $100 \%$, while only $62.5 \%$ of the seeds exposed to the same range of temperatures, but under continuous darkness, effectively germinated. The percentage of germination of seeds of $C$. hololeuca decreased when seeds changed from a regime of constant temperatures of $25^{\circ} \mathrm{C}$ to alternating temperatures (Fig. 1A). Under constant temperature of $25^{\circ} \mathrm{C}$, about $62 \%$ of the seeds germinated, whereas $50 \%$ of germination was observed for seeds under alternating temperatures between $20-35^{\circ} \mathrm{C}$.
Notwithstanding this perceptible decrease, it was only significant when we compared the values obtained under constant temperature, with those obtained under alternating temperatures between $20-35^{\circ} \mathrm{C}$ (SNK - $\left.\mathrm{P}<0.05\right)$.

Válio and Joly (1979) studied the germination of seeds of Cecropia glasioui, under $25^{\circ} \mathrm{C}$ and continuous light in the laboratory and observed $64 \%$ of germination, while under field conditions, with alternating temperatures between $15-32^{\circ} \mathrm{C}$ the percentage germination increased to $72 \%$. In conditions of continuous darkness, seeds of $C$. hololeuca exposed to constant temperatures of 25 , 30 and $35^{\circ} \mathrm{C}$ did not germinate. Thus, our results corroborate previous ones that showed that seeds of pioneer species, such as Cecropia obtusifolia and Piper auritum were totally dependent of light for the germination (Vasquez-Yanes and OroscoSegovia, 1984). Zaia and Takaki (1998) demonstrated that germination of seeds of Tibouchina pulchra and T. granulosa presented a strong light (white or red) dependence. These seeds did not germinate when exposed to continuous darkness or when irradiated with far-red light. In the darkness treatments, when the seeds were exposed to alternating temperatures of $20-25^{\circ} \mathrm{C}$, the percentage of germination observed was about $40 \%$. By increasing the range of alternating temperatures (20-30 ${ }^{\circ} \mathrm{C}$ and $20-35^{\circ} \mathrm{C}$ ), although we observed an increase in the percentage of germination to $50 \%$ (Fig. 1B) this increase was not significant (SNK - P $>0.05$ for all comparisons). In a pattern similar to the one observed for the percentage of germination, exposing the seeds to alternating temperatures suppressed the effects of the photoperiod on the mean velocity of germination. However, the magnitude of this effect varied as a function of the duration of the photoperiod and of the range of the alternating temperatures. In the darkness, when seeds where exposed to alternating temperatures of $20-30^{\circ} \mathrm{C}$ and $20-35^{\circ} \mathrm{C}$, the mean velocity of germination did not differ from the values observed for seeds exposed to the same range of alternating temperatures, but maintained under a photoperiod of 12 hours (Fig. 1C and 1D - SNK - P > 0.05 for all comparisons). 
Table 2 - Daily relative frequency of germination of Cecropia hololeuca as a function of temperature and photoperiod ( $\mathrm{L}-12$ hours photoperiod; D - continuous darkness).

\begin{tabular}{c|c|c|c}
\hline Treatment & $\begin{array}{c}\text { Onset of Germination } \\
(\text { day })\end{array}$ & $\begin{array}{c}\text { End of Germination } \\
\text { (day) }\end{array}$ & $\begin{array}{c}\text { \% Germination Peak } \\
\text { Value (day) }\end{array}$ \\
\hline $25^{\circ} \mathrm{C}-\mathrm{L}$ & 11 & 24 & $12.7 \%(15)$ \\
$20 / 25^{\circ} \mathrm{C}-\mathrm{L}$ & 13 & 30 & $18.3 \%(18)$ \\
$20 / 25^{\circ} \mathrm{C}-\mathrm{D}$ & 15 & 31 & $10.1 \%(28)$ \\
$20 / 30^{\circ} \mathrm{C}-\mathrm{L}$ & 12 & 32 & $16.5 \%(19)$ \\
$20 / 30^{\circ} \mathrm{C}-\mathrm{D}$ & 14 & 34 & $10.4 \%(21)$ \\
$20 / 35^{\circ} \mathrm{C}-\mathrm{L}$ & 18 & 33 & $11.4 \%(25)$ \\
$20 / 35^{\circ} \mathrm{C}-\mathrm{D}$ & 21 & 35 & $12.5 \%(27)$ \\
\hline
\end{tabular}

Seeds maintained in continuous darkness and exposed to alternating temperatures of $20-25^{\circ} \mathrm{C}$ showed a smaller and significant differences in mean velocity of germination when compared to seeds maintained under the same temperature regime (SNK - $\mathrm{P}<0.05$ ).

Changing seeds from a regime of constant temperature of $25^{\circ} \mathrm{C}$ to alternating temperature caused a decrease in the mean velocity of germination (Fig.1C).

This decrease, however, was only significant when the mean velocity of germination at $25^{\circ} \mathrm{C}(0.06)$ was compared to the mean velocity of germination for seeds exposed to alternating temperature of 20$35^{\circ} \mathrm{C}$ (0.039; SNK - P $\left.<0.05\right)$. Under continuous darkness, mean velocity of germination shifted from zero, when the seeds were continuously exposed to $25^{\circ} \mathrm{C}$, to 0.04 at alternating temperature of $20-25^{\circ} \mathrm{C}$. Further increases in the range of the alternating temperatures did not affect the mean velocity of germination (Fig. 1D; SNK - P > 0.05 for all comparisons). Amaral and Paulilo (1992) exposed seeds of Miconia cinnamomifolia to constant and alternating temperatures and found germination values for $25-30^{\circ} \mathrm{C}$ to be similar to values obtained under constant temperatures of $25^{\circ} \mathrm{C}$.

Seeds of Genipa americana, exposed to constant temperatures of 25,30 and $35^{\circ} \mathrm{C}$ showed, respectively, $90,3,86,7$ and $89,3 \%$ of germination, but only $12 \%$ when exposed to alternating temperatures of $20-30^{\circ} \mathrm{C}$ (Andrade et al. 2000). Except for seeds continuously maintained at $25^{\circ} \mathrm{C}$ and under a photoperiod of 12 hours, the distribution of the relative daily frequency of germination of $C$. hololeuca was heterogeneous and polimodal. Seeds began to germinate at the $11^{\text {th }}$ day after the onset of the experiment, when submitted to a continuous temperature of $25^{\circ} \mathrm{C}$ and a photoperiod of 12 hours (Table 2). On the other hand, seeds exposed to alternating temperatures of $20-35^{\circ} \mathrm{C}$ in continuous darkness seeds started to germinate only at the $22^{\text {nd }}$ day after the onset of experiment. Germination lasted until the $25^{\text {th }}$ day for seeds continuously exposed to $25^{\circ} \mathrm{C}$ at alternating temperature. regimes of $20-30^{\circ} \mathrm{C}$ and $20-35^{\circ} \mathrm{C}$, and maintained in continuous darkness, the germination extended up to the $35^{\text {th }}$ day.

Table 3 - Synchronization index for seeds of Cecropia hololeuca. Values followed by the same letter does not differ at the level $\propto=0.05$.

\begin{tabular}{l|r|r}
\hline Treatment & Light & Darkness \\
\hline $20^{\circ} \mathrm{C}$ & - & - \\
$25^{\circ} \mathrm{C}$ & $3.66 \mathrm{a}$ & - \\
$30^{\circ} \mathrm{C}$ & $1.64 \mathrm{~b}$ & - \\
$35^{\circ} \mathrm{C}$ & $2.66 \mathrm{c}$ & - \\
$40^{\circ} \mathrm{C}$ & - & - \\
$20 / 25^{\circ} \mathrm{C}$ & $3.50 \mathrm{a}$ & $3.64 \mathrm{a}$ \\
$20 / 30^{\circ} \mathrm{C}$ & $3.49 \mathrm{a}$ & $3.41 \mathrm{a}$ \\
$20 / 35^{\circ} \mathrm{C}$ & $3.46 \mathrm{a}$ & $3.30 \mathrm{a}$ \\
\hline
\end{tabular}

The highest daily value for frequency of germination (peak value) was observed for seeds maintained in a photoperiod of 12 hours, and exposed to alternated temperature of $20-25^{\circ} \mathrm{C}$ $(18.6 \%)$. On the other hand, seeds exposed to the same thermal regime, but maintained in continuous darkness, presented the lowest peak value $(10.1 \%)$. The distribution of the daily relative frequency of germination for seeds of $C$. hololeuca showed a high temporal variability, which could be due to a natural variability that results from the heterogeneous habitat where these species is commonly found. Moreover, these results suggest that, for this species, an asynchronous germination can safeguard a large efficiency in the establishment of its seedlings.

Seeds of $C$. hololeuca did not germinate under any of the photoperiods associated with a regime of "shade light" used in this study. We found that 
only 15 minutes of daily "shade light" were enough to inhibit the germination of seeds for this species. Seeds of $C$. hololeuca and $C$. pachystachya had its germination observed in the field under a R:FR ratio of 0.6 , whereby $83 \%$ and $85 \%$ of seeds germinated, respectively. When the ratio R:FR was reduced for 0.1 , seeds of $C$. hololeuca did not germinate, while the percentage for C. pachystachya was reduced to only $3 \%$ (Válio and Scarpa, 2001).

The distribution of the relative frequency of the germination for seeds of Salvia hispanica was polimodal, when the temperature reached the extreme limits. The delay in germination and its temporal distribution suggests an adaptation by seeds to increase the probability of seedling survival in highly heterogeneous habitats (Labouriau and Sharp, 1987).

Table 3 shows values for the synchronization index. Accordingly to Labouriau (1983), since seed germination is not totally synchronized, it is possible to quantify temporal variations in the rate of germination with this index. Small values indicate a high degree of synchronization, and the main advantage of this index is that it is not biased by the total number of germinated seeds or by the mean velocity of germination. (Santana and Ranal, 2000). We found that values of the synchronization index of germination for seeds of C. hololeuca exposed to a photoperiod of 12 hours was lower at constant temperatures of $30^{\circ} \mathrm{C}$. Regimes of alternating temperatures presented values for this index that did not significantly differed between the light and darkness conditions, as it was observed for values of mean velocity of germination. Thus, the regime of alterning temperatures totally suppressed the light requirement for germination of the seeds of $C$. hololeuca. Our results suggested that the alternating temperatures found in gaps could be perceived by seeds of $C$. hololeuca promoting seed germination and consequently this species was able to colonize those gaps under light or dark conditions.

\section{RESUMO}

Sementes de Cecropia hololeuca foram submetidas a regimes de temperaturas constantes e alternadas, associadas a fotoperíodos com luz branca, "luz de sombreamento" e escuro contínuo sob condições controlados em laboratório. Temperaturas constantes de $10^{\circ} \mathrm{C}$ a $20^{\circ} \mathrm{C}$ e acima de $35^{\circ} \mathrm{C}$, não promoveram a germinação. As sementes germinaram no escuro quando a temperatura foi alternada, e a "luz de sombreamento" a germinação. Concluímos que o regime de temperaturas alternadas suprimiu os efeitos da luz sobre a germinação.

\section{ACKNOWLEDGMENTS}

This study was partially supported by a CNPq graduate scholarship awarded to Simone Godoi. This study was supported by grants from FAPESP, CNPq and FUNDUNESP. M.T. is CNPq research fellow.

\section{REFERENCES}

Amaral, L. V. I. and Paulilo, M. T. S. (1991/1992), Efeito da luz, temperatura, reguladores de crescimento e nitrato de potássio na germinação de Miconia cinnamomifolia (D.C.) Naudin. Ïnsula, 21, 59-86.

Andrade, A. C. S et al. (2000), Seed germination of Genipa americana L.- Rubiaceae: temperature, substrate and post-seminal development. Pesquisa Agropecurária Brasileira, 35, 609-615.

Ballaré, C. L. (1994), Light Gaps: Sensing the Light Opportunities in Highly Dynamic Canopy Environments. In: Caldwell, M. M. and Percy, R. W. (eds.). Exploitation of Environmental Heterogeity by Plants: ecophysiological processes above and belowground. San Diego, CA : Academic Press, Inc. pp. 73-110.

Baroli, A. A. and Takaki, M. (2001), Phytochrome controls achene germination in Bidens pilosa L. (Asteraceae) by very low fluence response. Brazilian Archives of Biology and Technology, 44, 121-124.

Borges E. E. L. and Rena, A. B. (1993), Germinação de sementes. In: Aguiar, I. B.; Pinã-Rodrigues, F. C. M. and Figliolia, M. B. (eds). Sementes florestais tropicais. Brasília : Abrates. pp. 83-135.

Borthwick, H. et al. (1952), A reversible photoreaction controlling seed germination. Proceedings of National Academy of Sciences (USA), 38, 662-666.

Copeland, L. O. and Mcdonald, M. B. (1995), Principles of seed science and technology. $3^{\text {nd }}$ ed. Chapman e Hall. pp. 443-465.

Gandolfi, S. (2000), História natural de uma floresta estacional semidecidual no município de Campinas (São Paulo, Brasil). Ph.D. Thesis, Universidade Estadual de Campinas. 
Hartshorn, G. S. (1989), Application of gap theory to tropical Forest management: natural regeneration on strip clear-cuts in Peruvian Amazon. Ecology, 70, 567-569.

Labouriau, L. G. and Pacheco, A. (1978), On the frequency of isothermal germination in seeds of Dolichos biflorus L. Plant and Cell Physiology, 19, 507-512.

Labouriau, L. G. and Agudo, M. (1978), On the physiology of seed germination in Salvia hispanica L. I. Temperature effects. Anais da Academia Brasileira de Ciências, 59, 37-56.

Lorenzi, H. (1992), Árvores Brasileiras: manual de identificação e cultivo de plantas arbóreas nativas do Brasil. São Paulo : Plantarum. pp. 351.

Malavasi, M. M. (1988), Germinação de sementes. In: Rodrigues, F. C. M. (coord.). Manual de Análise de Sementes florestais. Campinas : Fundação Cargill. pp. 25-39.

Mancinelli, A. L. (1994), The physiology of phytochrome action. In: Kendrick, R. E. and Kronenberg, G. H. M. (eds.). Photomorphogenesis in Plants. $2^{\text {nd }}$ ed. Dordrecht : Kluwer Ac Publ. pp. 211-269.

Orozco-Segovia, A. and Vázquez-Yanes, C. (1992), Los sentidos de las plantas, la sensibilidade de las semillas a la luz. Ciencia, 43, 399-411.

Santana, D. G. and Ranal, M. A. (2000), Análise estatistica na germinação. Revista Brasileira de Fisiologia Vegetal, 12 : (esp.), 205-237.

Smith, W. K.; Knapp, A. K. and Reiners, W. A. (1989), Penumbral effects on sunlight penetration in plant comuities. Ecology, 70, 1603-1609.

Sokal, R. R. and Rohlf, F. J. (1998), Biometry. $2^{\text {nd }}$ ed. San Francisco : Freemn Company.

Válio, I. F. M. and Joly, C. A. (1979), Light sensivity of the seeds on the distribuition of Cecropia glasiovii Snethlage (Moraceae). Zeitschrift für Pflanzenphysiologie, 91, 371-376.
Válio, I. F. M. and Scarpa, F. M. (2001), Germination of seeds of tropical pionner species under controlled and natural conditions. Revista Brasileira de Botânica, 24, 79-84.

Vázquez-Yanes, C. and Orozco-Segovia, A. (1993), Patters of seed longevity and germination in tropical rain forest. Annual Review in Ecology and Systematics, 24, 69-87.

Vázquez-Yanes, C. and Orozco-Segovia, A. (1984), Fisiologia Ecologica de las semillas de árboles de la selva tropical. Ciencia, 35, 191-201.

Wayne, P. M. and Bazzaz, F. A. (1993), Morning vs afternoon sun patches in experimental forest gaps: consequenses of temporal incogruency of resources to birch regeneration. Oecologia, 94, 235-243.

Whithmore, T. C. (1989), Canopy gaps and two major groups of forest trees. Ecology, 70, 536-538.

Zaia, J. E. and Takaki, M. (1998), Estudo da germinação de sementes de espécies arbóreas pioneiras:Tibouchina pulchra Cogn. e Tibouchina granulosa Cogn. (Melastomataceae). Acta Botanica Brasilica, 12, 221-229.
Received: April 10, 2002; Revised: January 09, 2003; Accepted: April 28, 2003. 